\title{
Bacterial adherence to graft tissues in static and flow conditions
}

Tiago Rafael Veloso, PhD, ${ }^{\mathrm{a}}$ Jorien Claes, PhD, ${ }^{\mathrm{a}}$ Soetkin Van Kerckhoven, ${ }^{\mathrm{b}}$ Bartosz Ditkowski, PhD, ${ }^{\mathrm{a}}$

Luis G. Hurtado-Aguilar, MSc, ${ }^{c}$ Stefan Jockenhoevel, MD, PhD, ${ }^{c}$ Petra Mela, PhD,

Ramadan Jashari, MD, PhD, ${ }^{\mathrm{d}}$ Marc Gewillig, MD, PhD, ${ }^{\mathrm{a}}$ Marc F. Hoylaerts, PhD, ${ }^{\mathrm{b}}$ Bart Meyns, MD, PhD, and Ruth Heying, MD, $\mathrm{PhD}^{\mathrm{a}}$

\section{ABSTRACT}

Background: Various conduits and stent-mounted valves are used as pulmonary valve graft tissues for right ventricular outflow tract reconstruction with good hemodynamic results. Valve replacement carries an increased risk of infective endocarditis (IE). Recent observations have increased awareness of the risk of IE after transcatheter implantation of a stent-mounted bovine jugular vein valve. This study focused on the susceptibility of graft tissue surfaces to bacterial adherence as a potential risk factor for subsequent IE.

Methods: Adhesion of Staphylococcus aureus, Staphylococcus epidermidis, and Streptococcus sanguinis to bovine pericardium (BP) patch, bovine jugular vein (BJV), and cryopreserved homograft $(\mathrm{CH})$ tissues was quantified under static and shear stress conditions. Microscopic analysis and histology were performed to evaluate bacterial adhesion to matrix components.

Results: In general, similar bacteria numbers were recovered from $\mathrm{CH}$ and BJV tissue surfaces for all strains, especially in flow conditions. Static bacterial adhesion to the $\mathrm{CH}$ wall was lower for $S$ sanguinis adhesion $(P<.05$ vs BP patch). Adhesion to the BJV wall, $\mathrm{CH}$ wall, and leaflet was decreased for $S$ epidermidis in static conditions $(P<.05$ vs BP patch). Bacterial adhesion under shear stress indicated similar bacterial adhesion to all tissues, except for lower adhesion to the BJV wall after $S$ sanguinis incubation. Microscopic analysis showed the importance of matrix component exposure for bacterial adherence to $\mathrm{CH}$.

Conclusions: Our data provide evidence that the surface composition of BJV and $\mathrm{CH}$ tissues themselves, bacterial surface proteins, and shear forces per se are not the prime determinants of bacterial adherence. (J Thorac Cardiovasc Surg 2018;155:325-32)

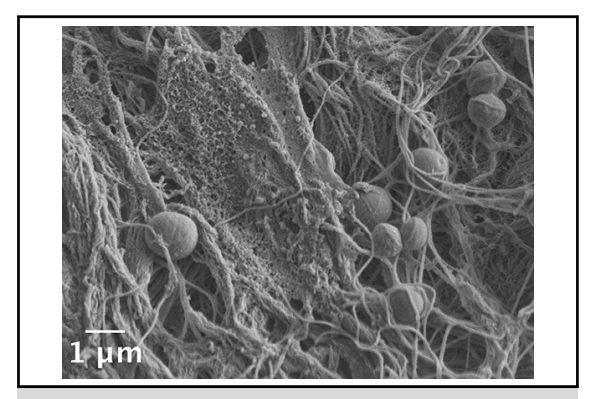

Visualization of $S$ aureus Cowan adhesion to the BJV conduit wall using scanning electron microscopy.

\section{Central Message}

Graft tissue surface structure, source, and bacterial surface proteins are not prime determinants of bacterial adhesion to graft tissues used for right ventricular outflow tract reconstruction in static and flow conditions.

\section{Perspective}

As a first step to exploring the complex processes that initiate IE, we have clarified bacterial adhesion to different graft tissues in vitro. Future studies will use the flow model to investigate the impact of plasma proteins, platelets, and inflammatory cells to bacterial adhesiveness. Increased knowledge of these factors will facilitate further studies using in vivo models of IE pathogenesis in graft conduits.

See Editorial Commentary page 333.
Infective endocarditis (IE) remains a diagnostic and therapeutic challenge associated with high morbidity and mortality and is especially prevalent in patients with congenital

From the ${ }^{\mathrm{a} C a r d i o v a s c u l a r}$ Developmental Biology, ${ }^{\mathrm{b}}$ Center for Molecular and Vascular Biology, ${ }^{\mathrm{e}}$ Division of Clinical Cardiac Surgery, Department of Cardiovascular Sciences, KU Leuven, Leuven, and ${ }^{\mathrm{d}}$ European Homograft Bank, Saint Jean Clinique, Brussels, Belgium; and ${ }^{\mathrm{c} D e p a r t m e n t}$ of Tissue Engineering and Textile Implants, AME-Helmholtz Institute for Biomedical Engineering, Aachen, Germany.

Funding: This study was sponsored by a grant of the Research Fund KU Leuven (OT/ 14/097) given to R.H. T.R.V. is Postdoctoral Fellow of the FWO Research Foundation - Flanders (Grant 12K0916N) and R.H. is supported by the Clinical Research Fund of UZ Leuven. and acquired heart valve disease. ${ }^{1}$ Novel therapeutic strategies for valve replacement in the right ventricular outflow tract (RVOT) have improved patients' quality of life,

Received for publication Nov 29, 2016; revisions received May 19, 2017; accepted for publication June 1, 2017; available ahead of print July 13, 2017.

Address for reprints: Ruth Heying, MD, PhD, Cardiovascular Development Biology, Cardiovascular Sciences Department, KU Leuven, Box 911, Herestraat 49, 3000 Leuven, Belgium (E-mail: ruth.heying@uzleuven.be).

0022-5223/\$36.00

Copyright (C) 2017 by The American Association for Thoracic Surgery http://dx.doi.org/10.1016/j.jtcvs.2017.06.014 

Abbreviations and Acronyms
$\mathrm{BJV}=$ bovine jugular vein
$\mathrm{BP}=$ bovine pericardium
$\mathrm{CFU}=$ colony-forming unit
$\mathrm{CH}=$ cryopreserved homograft
$\mathrm{EC}=$ endothelial cell
$\mathrm{ECM}=$ extracellular matrix
IE $=$ infective endocarditis
MSB = Martius scarlet blue
PBS = phosphate-buffered saline
RVOT $=$ right ventricular outflow tract
SEM = scanning electronic microscope
$\mathrm{VWF}=$ von Willebrand factor

conduits, ${ }^{14,15}$ creating the optimal conditions for the onset of IE in such lesions.

In this study, we aimed to investigate the susceptibility of bovine pericardium (BP), BJV tissue, and $\mathrm{CH}$ tissue for bacterial adherence. Major relevant bacteria causing IE, as staphylococci and streptococci, were evaluated using an in vitro experimental setup to assess adherence to different graft tissues under static and shear stress conditions. Tissue surface composition and flow were tested as differential determinants of bacterial adhesion during the initial onset of IE. Better insight into these mechanisms may help identify factors to prevent bacterial adhesion. Our findings from this study will aid the construction of more complex in vitro models, including additional players relevant in the onset of IE, associated with graft tissues.

\section{METHODS}

\section{Bacterial Strains and Growth Conditions}

We used 3 well-described bacterial isolates in this study, including $S$ aureus Cowan (ATCC 12598), S epidermidis ATCC 149900, and $S$ sanguinis NCTC 7864. S aureus and S epidermidis were grown at $37^{\circ} \mathrm{C}$ in tryptic soy broth (Fluka, Steinheim, Germany), and S sanguinis was grown at $37^{\circ} \mathrm{C}$ with $5 \% \mathrm{CO}_{2}$ in brain heart infusion broth (Fluka).

\section{Graft Tissues Studied}

The BP patch (Supple Peri-Guard Pericardium; Synovis Surgical Innovations, St. Paul, Minn), $\mathrm{CH}$ tissue processed by the European Homograft Bank (EHB; stored at $-80^{\circ} \mathrm{C}$ until use), and heterologous BJV (Contegra conduit; Medtronic, Minneapolis, Minn) were used to investigate bacterial adhesion. For the BJV conduit and $\mathrm{CH}$, both the wall and valvular leaflets were used. The BP patch and BJV conduit were purchased from the manufacturers. The $\mathrm{CH}$ thawing process was done in accordance with instructions from the EHB. ${ }^{7}$ All tissues were rinsed using $0.9 \% \mathrm{NaCl}$ before use. A 10-mm Acu-Punch (Acuderm, Fort Lauderdale, Fla) was used to cut circular tissue pieces, as illustrated in Video 1. Pieces of BJV conduit were incubated overnight at $4^{\circ} \mathrm{C}$ with $200 \mathrm{~g} / \mathrm{L}$ of human albumin (Flexbumin; Baxter, Westlake Village, Calif) to neutralize glutaraldehyde (protocol optimized during preliminary experiments), and were then rinsed with $0.9 \% \mathrm{NaCl}$. Bacterial adhesion was assessed for at least 5 to 17 different tissues pieces, except for the BJV leaflet (3 pieces). A graft tissue sample incubated in PBS served as a negative control.

\section{Bacterial Adhesion Under Static Conditions}

Washed 10-mm tissue pieces were placed on poly-(methyl methacrylate) inlets with ring rubber gaskets (in-house design; Figure E1 and Video 1) mounted in a 6-well plate (Nunc, Roskilde, Denmark) and fixed using a metal frame (in-house design; Figure E1 and Video 1). This design allows bacterial contact exclusively on the inner part of the graft tissues. Bacterial inocula were prepared by washing cultures overnight with phosphate saline buffer (PBS) and then labeling them with 5(6)-carboxy-fluorescein $N$-hydroxy-succinimidyl ester $(30 \mu \mathrm{g} / \mathrm{mL}$; Sigma-Aldrich, $\mathrm{St}$ Louis, Mo) for 30 minutes. After washing with PBS, bacteria were diluted to $10^{7}$ colony-forming units (CFU)/mL (verified by CFU counting) in PBS. Then a bacterial suspension corresponding to $10^{7} \mathrm{CFU} / \mathrm{mL}$ was added to the tissue pieces, allowing adherence for 1 hour at $37^{\circ} \mathrm{C}$, as described previously. ${ }^{16,17}$ The 1 -hour incubation period is a standardized time frame for sufficient bacterial adhesion, during which differentiation of S aureus, Sepidermidis, and $S$ sanguinis binding is possible. ${ }^{17}$ Subsequently, the tissue pieces were washed with PBS, cut using an 8-mm Acu-Punch, and transferred into a tube containing $1 \mathrm{~mL}$ of $0.9 \% \mathrm{NaCl}$, which was then sonicated 


\section{BACTERIAL ADHESION TO GRAFT TISSUES IN STATIC AND FLOW CONDITIONS TR VELOSO, J CLAES, S VAN KERCKOVEN, LG HURTADO-AGUILAR, $S$ JOCKENHOEVEL, P MELA, R JASHARI, M GEWILLIG, MF HOYLAERTS, B MEYNS AND R HEYING}

VIDEO 1. Visualization of the experimental procedure to assess bacterial adhesion to graft tissues under static and flow conditions. The tissue preparation, mounting of the tissue in the well plate, with the use of a metal frame (static conditions) and mounting the tissue in the flow chamber is shown. In the experimental setup for static bacterial adhesion, the inlets restrain the bacterial contact to the inner surface of the tissues exclusively. The tissue pieces are mounted in the flow chamber with the inner surface facing up and in contact with the bacterial suspension. The tissue piece is placed between a Lumox slide (with an $8 \mathrm{~mm}$ circular perforation to allow contact of the tissue with the bacterial suspension) and a rubber gasket, to prevent dislocation of the tissue piece during the perfusion. The investigated tissue (smaller diameter) is not manipulated by the forceps. The aim of the experimental procedure is to investigate the impact of the tissue surface composition and its origin on bacterial adhesion, especially under shear stress conditions. Video available at: http://www. jtcvsonline.org/article/S0022-5223(17)31186-8/fulltext.

for 10 minutes using a sonication bath (VWR Ultrasonic Cleaner; VWR, Radnor, Pa). The bacterial suspension was serially diluted and spread onto Mueller Hinton blood agar plates for CFU counting. The results are presented as CFU/ $\mathrm{cm}^{2}$. Scanning electronic microscopy (SEM) and histological analysis were performed following routine procedures.

\section{Bacterial Adhesion Under Flow Conditions}

Identically prepared tissue pieces were mounted in a newly developed flow chamber (in-house design at the AME-Helmholtz Institute for Biomedical Engineering, Aachen, Germany; Figure E1 and Video 1). Tissues were perfused with a suspension of $10^{7} \mathrm{CFU} / \mathrm{mL}$ fluorescent-labeled bacteria (in PBS; verified by CFU counting) at 10 dyne $/ \mathrm{cm}^{2}$ with a peristaltic pump (Ismatec BVP-Z Standard; Cole Parmer, Wertheim, Germany) for 1 hour, ${ }^{18}$ with the bacterial reservoir set at $37^{\circ} \mathrm{C}$. The bacterial suspension (total volume $100 \mathrm{~mL}$ ) was allowed to recirculate. After perfusion, tissue pieces were rinsed briefly and treated as described above.

\section{SEM and Histology}

Bacterial adhesion was visualized using the IN Cell Analyzer 2000 (GE Healthcare Life Sciences, Pittsburgh, Pa). The tissue pieces were processed for SEM as described by Vanassche et $\mathrm{al}^{19}$ and scanned using a serial blockface electron microscopy field emission (Sigma; Zeiss, Germany). For histological analysis, tissue pieces were fixed overnight in $4 \%$ paraformaldehyde embedded in paraffin and stained with Martius scarlet blue (MSB) or immunohistochemically for von Willebrand factor (VWF), in case of the $\mathrm{CH}$ samples.

\section{Statistical Analysis}

The bacterial loads, presented as $\mathrm{CFU} / \mathrm{cm}^{2}$, were compared across graft tissues within the same condition (static or flow) using Kruskal-Wallis 1way analysis of variance followed by Dunn's multiple-comparisons test. The same analysis was performed to compare bacterial adhesion for different bacteria to a given tissue in static and flow conditions. All statistical analyses were performed with the GraphPad Prism version 6.0 for Mac OS X; (GraphPad Software, La Jolla, Calif). Differences were considered significant at $P<.05$ (2-sided significance levels).

\section{RESULTS}

\section{$S$ aureus Adhesion to Different Graft Tissues}

The ability of $S$ aureus Cowan to adhere to the various graft tissues was not significantly different when tested in static conditions (Figure 1, A). Under shear stress (Figure 1,B), we also observed a similar degree of $S$ aureus adhesion to all graft tissues, yet with a nonsignificant trend toward greater adhesion to the $\mathrm{CH}$ leaflets.

\section{S epidermidis Adhesion to the Different Graft Tissues}

Under static conditions, we found similar $S$ epidermidis adhesion to the BP patch and BJV leaflet tissue, but decreased adhesion to the BJV wall, $\mathrm{CH}$ wall, and $\mathrm{CH}$ leaflet tissue (Figure 2, $A ; P<.05$ ). Under shear stress conditions, no relevant differences in bacterial attachment were observed across the various graft tissues (Figure 2, B).

\section{$S$ sanguinis Adhesion to the Different Graft Tissues}

$S$ sanguinis NCTC 7864 shows reduced adhesion, especially to the $\mathrm{CH}$ wall, compared with that to $\mathrm{BP}$ patch tissue in static conditions (Figure $3, A ; P<.05$ ), whereas adhesion to BJV leaflets was comparable. A nonsignificant trend toward lower adhesion to the BJV wall and $\mathrm{CH}$ leaflets was observed. In flow conditions, compared with the BP patch, reduced bacterial adherence only to the BJV wall was observed (Figure 3, $B ; P<.05$ ).

\section{Graft Tissues Show Similar Susceptibility to Bacterial Adhesion}

Comparison of bacterial adhesion of the different bacterial species on a given graft tissue revealed similar adhesion to the BP patch and BJV conduit leaflets for the 3 bacteria in both static experiments (Figures 1-3, A) and flow experiments (Figures 1-3, B). In contrast, in static experiments, $S$ aureus bound significantly stronger on the BJV wall compared to $S$ epidermidis $(P<.05)$. In flow experiments, $S$ sanguinis showed significantly lower adhesion compared with $S$ aureus and $S$ epidermidis for the BVJ wall $(P<.05)$. In the $\mathrm{CH}$ wall, $S$ sanguinis showed lower adhesion compared with $S$ aureus and $S$ epidermidis in static conditions $(P<.05)$. Finally, $S$ aureus showed higher adhesion $(P<.05)$ to $\mathrm{CH}$ leaflets compared with $S$ sanguinis in the static experiments.

\section{Microscopic Analysis of Bacterial Adhesion to Graft Tissues}

Figure 4 depicts bacterial adhesion of $S$ aureus to BJV and $\mathrm{CH}$ graft tissues visualized by SEM with MSB. Likewise, Figure 5 shows immunohistochemical VWF staining of $\mathrm{CH}$ graft tissue. These microscopical approaches revealed that bacteria adhere in a uniform pattern over the entire graft surface, prominently in a single-cell manner (Figures 4 and 5, A), although small bacterial aggregates 


\section{S. aureus Cowan}

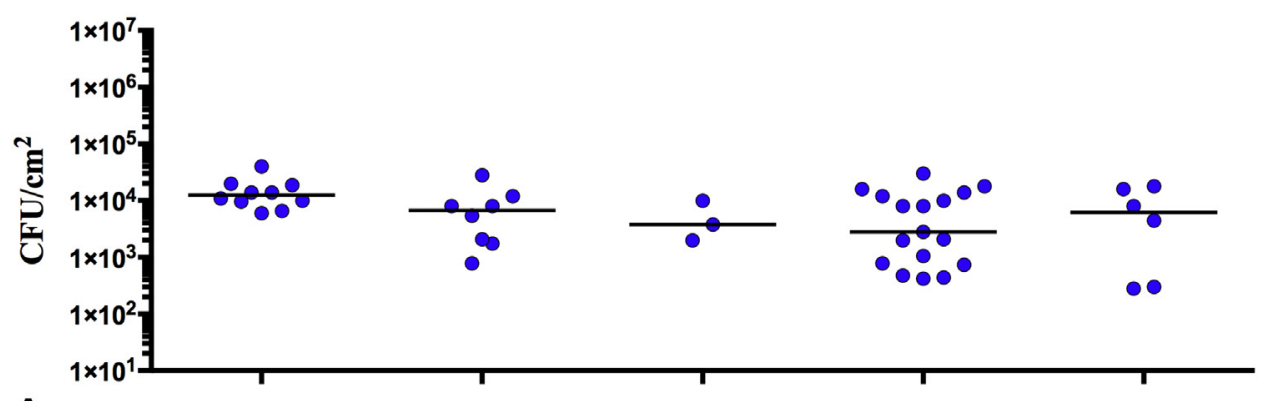

A

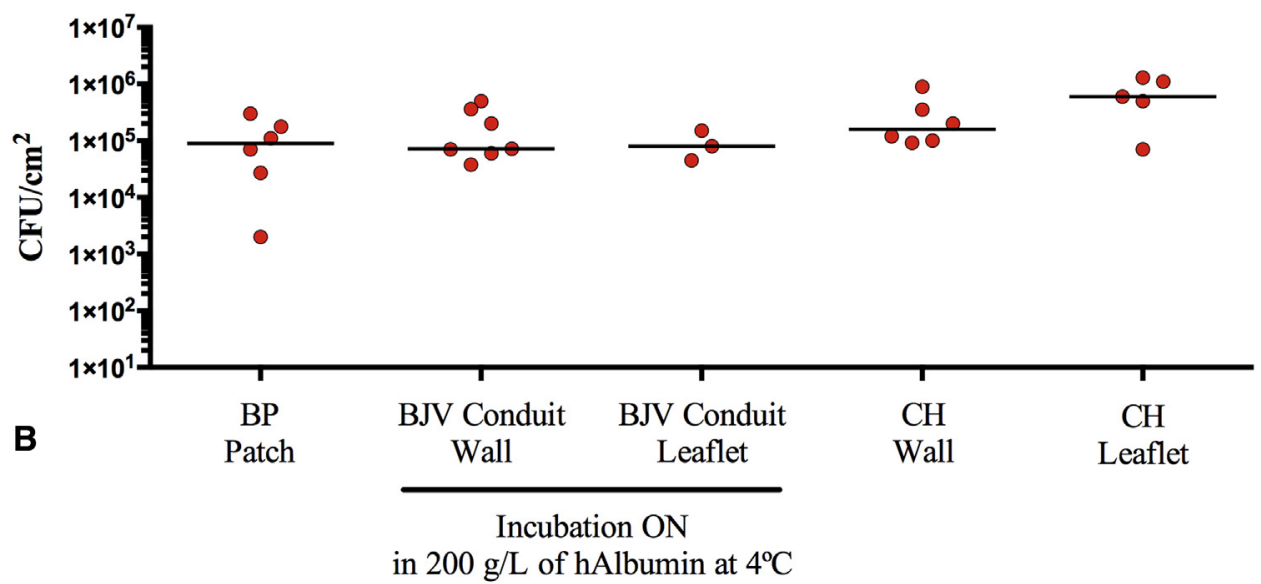

FIGURE 1. Adhesion of S aureus Cowan to graft tissues under static (A, blue dots) and flow (B, red dots) conditions. Bacterial adhesion was assessed as the CFU growing on Mueller Hinton blood agar plates after serial dilution of the bacterial suspension recovered from infected graft tissue pieces after sonication (expressed as $\mathrm{CFU} / \mathrm{cm}^{2}$ ). Median (interquartile range) for the initial inocula was 7.1 (6.8-7.3) $\log _{10}$ CFU. Each dot represents 1 observation; the bar represents the median value. $C F U$, Colony-forming unit; $B P$, bovine pericardium; $B J V$, bovine jugular vein; $C H$, cryopreserved homograft; $O N$, overnight.

were found as well (Figures 4 and 5, A; also Figures E2E4). The images obtained by SEM revealed an absence of ECs on the $\mathrm{CH}$ tissue surface and show exposed ECM (Figure 4). On the other hand, the histological analysis after MSB staining showed graft tissues with intact morphological structures composed mainly of collagen fibers and elastin fibers, further illustrating the presence of bacteria attached to the tissue surface (indicated by black arrows in the inserts; Figure E5, $A$ ). Detailed analysis, after VWF staining (Figure E5, B) confirmed that the ECM on the homograft surface had VWF interruptions, corroborating the SEM analysis (Figure E4). No noticeable difference was observed in the SEM image analysis after adhesion of $S$ epidermidis or $S$ sanguinis to the BJV wall and the $\mathrm{CH}$ wall (Figures E5 and E6).

\section{DISCUSSION}

Clinical observations have focused attention on IE as one of the mid-term complications after successful
RVOT valve replacement. Indeed, different studies have raised awareness that the risk of IE is increased after implantation of a heterologous BJV conduit compared with $\mathrm{CH}^{2,3}$

A first and critical step in the pathogenesis of IE is the bacterial adhesion directly to the inflamed or damaged endothelium $^{1}$ and/or to the implanted conduits. ${ }^{14,15}$ In this study, we investigated whether the primary bacterial adhesion to graft tissues used for RVOT reconstruction could be linked to structural differences of the tissues, bacterial species specificity, and extracellular exposed substrates, analyzing adhesion both under static and flow conditions, the latter to include hemodynamic aspects of interactions.

Our results show that $\mathrm{BJV}$ and $\mathrm{CH}$ graft tissue had similar susceptibility toward recruitment of all 3 bacteria when tested in static or flow conditions. These data suggest that the surface structure, the source of the tissue itself, the nature of bacterial surface proteins, and the presence of shear 


\section{S. epidermidis ATCC 149900}

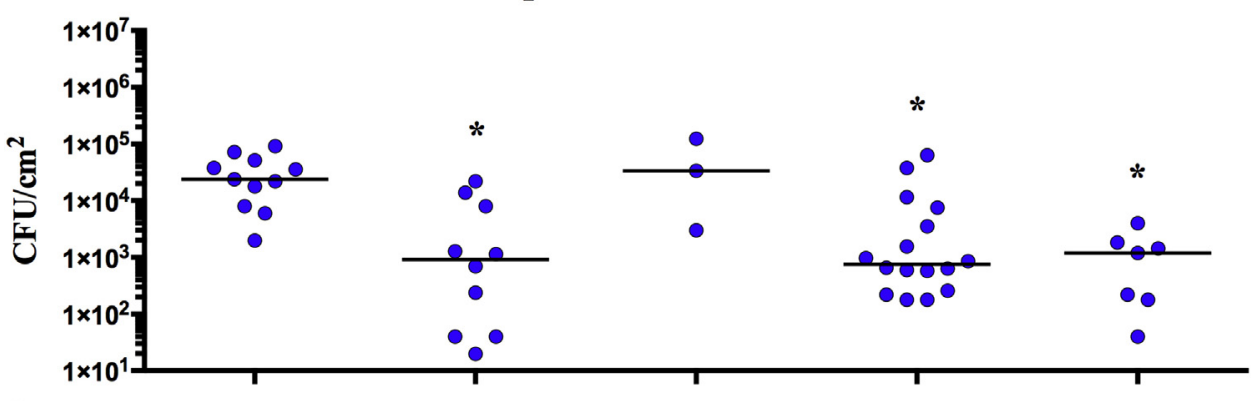

A

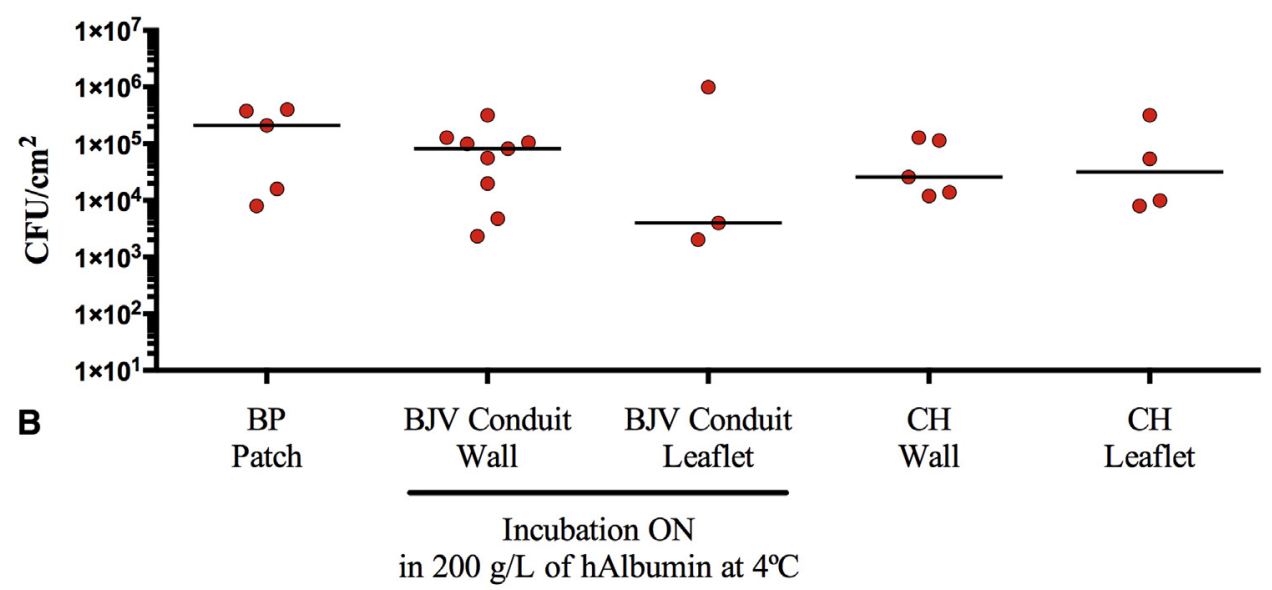

FIGURE 2. Adhesion of S epidermidis ATCC 149900 to graft tissues under static (A, blue dots) and flow (B, red dots) conditions. Bacterial adhesion was assessed as the $\mathrm{CFU}$ growing on Mueller Hinton blood agar plates after serial dilution of the bacterial suspension recovered from infected graft tissue pieces after sonication (expressed as $\mathrm{CFU} / \mathrm{cm}^{2}$ ). Median (interquartile range) for the initial inocula was 7.0 (6.7-7.2) $\log _{10} \mathrm{CFU}$. *P<.05, compared with the BP patch under static conditions. Each dot represents 1 observation. The bar represents the median value. $C F U$, Colony-forming unit; $B P$, bovine pericardium; $B J V$, bovine jugular vein; $\mathrm{CH}$, cryopreserved homograft; $\mathrm{ON}$, overnight.

forces per se are not prime determinants during initial bacterial adherence. Yet detailed analysis in stasis of $S$ epidermidis adherence to $\mathrm{BJV}$ wall, $\mathrm{CH}$ wall and leaflet, and of $S$ sanguinis adherence to the $\mathrm{CH}$ wall revealed 10- to 100 fold less adhesion compared with that of the BP patch, indicative of intrinsic bacterial factors involved in the control of static binding. In contrast, in conditions where shear forces are applied, bacterial adherence to all tested graft tissues was similar, except that of $S$ sanguinis to the BJV wall, which was reduced compared with that to the BP patch.

Bacterial adhesion is dependent on the balance between dispersive hydrodynamic forces and the adhesive forces generated by the interactions of membrane-bound receptors and their ligands. ${ }^{20} S$ aureus adhesion to platelets via $S$ aureus protein A; $S$ aureus clumping factor A; $S$ aureus serine-aspartate repeat proteins $\mathrm{C}, \mathrm{D}$, and $\mathrm{E}^{21}$; and $\mathrm{VWF}^{22}$ are flow-dependent interactions and as such demonstrate the importance of shear in $S$ aureus pathogenesis. Little information on S epidermidis and S sanguinis pathogenesis is available. Bacteria also can exhibit stochastic interactions of nonproteinaceous components of the cell wall (eg, polysaccharide dextran) and surfaces that promote bacterial adhesion, ${ }^{23,24}$ processes further regulated by shear stress during contact.

A more constant high adherence to graft tissue for $S$ aureus compared with $S$ epidermidis and $S$ sanguinis has been reported in previous in vitro studies of adhesion to human and canine aortic valve leaflets. ${ }^{25}$ Likewise, increased in vitro adhesion to endothelial cells (ECs) and their invasion have been reported. ${ }^{17}$

The SEM analysis of the graft tissues is suggestive of some tissue surface differences that may explain the bacterial adherence profile, presently observed. The apparent trend of increased adhesion of $S$ aureus Cowan to $\mathrm{CH}$ leaflets under flow seemed to coincide with the absence of ECs on the major surface area with exposed ECM components, 


\section{S. sanguinis NCTC 7864}

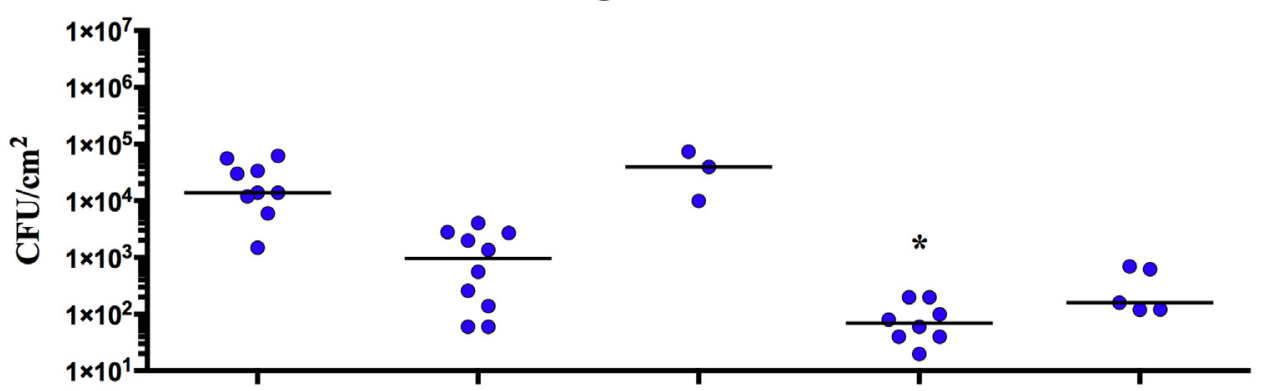

A

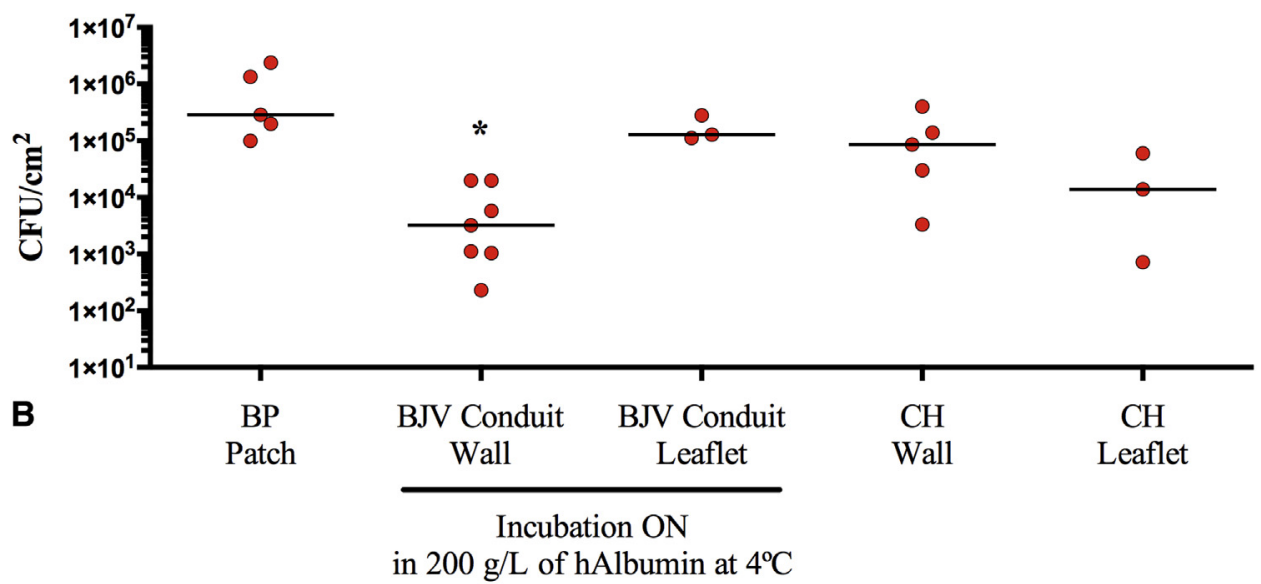

FIGURE 3. Adhesion of S sanguinis NCTC 7864 to graft tissues under static (A, blue dots) and flow (B, red dots) conditions. Bacterial adhesion was assessed as the CFU growing on Mueller Hinton blood agar plates after serial dilution of the bacterial suspension recovered from infected graft tissue pieces after sonication (expressed as $\mathrm{CFU} / \mathrm{cm}^{2}$ ). Median (interquartile range) for the initial inocula was 7.0 (6.7-7.2) $\log _{10} \mathrm{CFU}$. $* P<.05$ compared with the BP patch under flow conditions. Each dot represents 1 observation. The bar represents the median value. $C F U$, Colony-forming unit; $B P$, bovine pericardium; $B J V$, bovine jugular vein; $\mathrm{CH}$, cryopreserved homograft; $\mathrm{ON}$, overnight.

an interpretation supported by VWF immunohistochemistry, which also revealed de-endothelialized areas. The chemical cross-linking process in the BP patch and BJV conduit may affect ECM accessibility for bacterial adhesion. Koolbergen et $\mathrm{al}^{26}$ reported total or partial absence of ECs on the surface of cryopreserved human allografts after storage and thawing. Even when neoendothelialization of cryopreserved aortic homografts and Melody valves was observed by Schneider et $\mathrm{al}^{27}$ thrombotic material was detected on the basis of valve cusps in 4 patients, 3 of whom presented with IE on explanted graft tissues after failure. ${ }^{27}$

A recent assessment of in vitro bacterial adhesion to BP patch and Melody valve surfaces by Jalal et $\mathrm{al}^{16}$ reported a greater susceptibility of the Melody valve surface for $S$ aureus and $S$ sanguinis adhesion compared with BP and porcine pericardium, findings at variance with our present data. In our study, only the inner part of the graft tissues was exposed to bacteria owing to the use of inlets, reducing potential nonspecific bacterial binding to the outer side of the graft tissue. In this way, we attempted to more accurately mimic in vivo perfusion, where only the inner graft surface is in contact with the bloodstream and is exposed to bacteremia. Furthermore, bacterial strains tested by Jalal et $\mathrm{al}^{16}$ are clinical isolates from patients, diagnosed with Melody valve IE. Clinical strains, especially those of $S$ aureus, can be more virulent owing to the presentation of more pathogenetic surface molecules, including distinct polymorphisms of adhesion molecules (eg, FnBPA) that allow these isolates to preferentially bind and infect medical devices. ${ }^{28}$ In addition, the crimping process of the Melody valve was found to increase bacterial adhesion, possibly owing to damage to the BJV conduit structure. ${ }^{29}$ We did not assess the crimping process, because we investigated BJV tissue and not the stent-mounted Melody valve. Moreover, the 2 studies involved different BP tissue preparation 

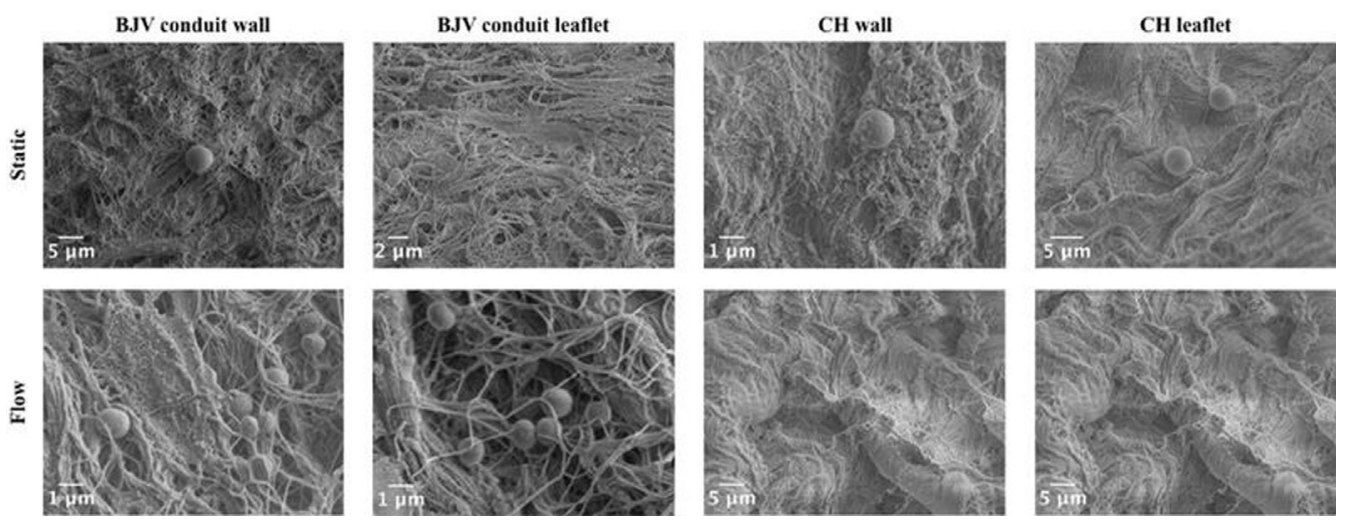

FIGURE 4. Visualization of $S$ aureus Cowan adhesion to graft tissues, after scanning electronic microscopy of the indicated tissues, collected after static incubation or after perfusion, as indicated (left to right: BJV conduit wall, BJV conduit leaflet, $\mathrm{CH}$ wall, and $\mathrm{CH}$ leaflet). BJV, Bovine jugular vein; $\mathrm{CH}$, cryopreserved homograft.

processes by different suppliers. In the present study we also intended to assess interactions in more physiological shear stress, thought to be a major determinant in the onset of IE; however, we found that shear stress tended to flatten out the variability in adhesion profiles, measured in stasis, between different bacteria and graft tissues tested; that is, the role of specific bacterial adhesive factors was diminished by flow.

Nonetheless, the greater susceptibility of the Melody valve surface for $S$ aureus and $S$ sanguinis adhesion compared with BP and porcine pericardium suggests the need for exploration of additional factors to model bacterial adhesion to graft tissue. In our model, we can now investigate the impact of plasma proteins (fibrinogen and immunoglobulins) and blood cells (platelets and leukocytes) on bacterial adhesiveness in conditions where shear forces are more directly implicated in controlling bacterial adhesiveness. $S$ aureus pathogenesis depends on interactions with all these components for its binding to ECs, which further depends on bacterial coagulation control. ${ }^{11}$
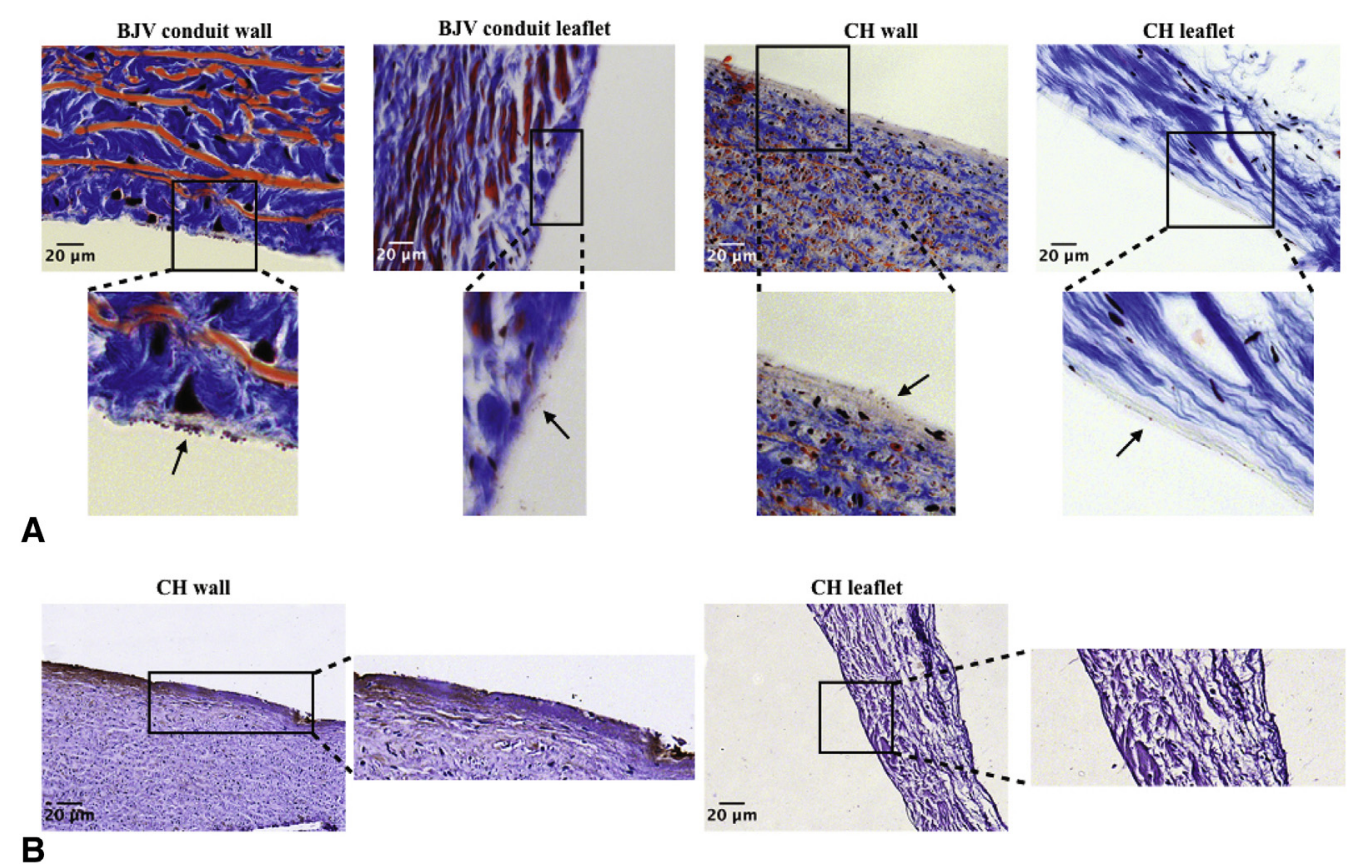

FIGURE 5. MSB histological analysis of $S$ aureus adhesion to graft tissues (Left to right: BJV wall; BJV leaflet; $\mathrm{CH}$ wall, and $\mathrm{CH}$ leaflet) and VWF immunohistochemistry (left to right: $\mathrm{CH}$ wall and $\mathrm{CH}$ leaflet, noninfected control). The lower panel in (A) represents a magnification of the square indicated in the original image and black arrows indicate bacteria attached to the tissue surface. The lower panel of (B) represents a magnification of the square indicated in the original image. $B J V$, Bovine jugular vein; $C H$, cryopreserved homograft. 
Correspondingly, the thrombogenicity of graft tissues, as well as the degree of neo-endothelization, will require precise assessment. Preclinical and clinical analyses of the flow dynamics $^{30}$ after RVOT reconstruction with the different graft tissues might elucidate the importance of hemodynamic and shear stress conditions in vivo.

In conclusion, in flow conditions especially, bacterial adhesiveness to graft tissue depends to only a minor degree on the strain analyzed and on morphological tissue differences in various graft tissues, necessitating the inclusion of more accurate hemodynamic flow parameters to understand the mechanisms dictating initial bacterial adherence to implanted graft tissue.

\section{Conflict of Interest Statement}

M.G. is a proctor for Medtronic and Edwards. All other authors have nothing to disclose with regard to commercial support.

\section{References}

1. Que YA, Moreillon P. Infective endocarditis. Nat Rev Cardiol. 2011:8:322-36.

2. McElhinney DB, Benson LN, Eicken A, Kreutzer J, Padera RF, Zahn EM. Infective endocarditis after transcatheter pulmonary valve replacement using the Melody ${ }^{\circledR}$ valve: combined results of 3 prospective North American and European studies. Circ Cardiovasc Interv. 2013;6:292-300.

3. Hill EE, Herijgers P, Claus P, Vanderschueren S, Peetermans WE, Herregods MC. Clinical and echocardiographic risk factors for embolism and mortality in infective endocarditis. Eur J Clin Microbiol Infect Dis. 2008;27:1159-64.

4. Mery CM, Guzmán-Pruneda FA, De León LE, Zhang W, Terwelp MD, Bocchini CE, et al. Risk factors for development of endocarditis and reintervention in patients undergoing right ventricle to pulmonary artery valved conduit placement. J Thorac Cardiovasc Surg. 2016;151:432-9. 441.e1-2.

5. Troost E, Meyns B, Daenen W, Van de Werf F, Gewillig M, Van Deyk K, et al. Homograft survival after tetralogy of Fallot repair: determinants of accelerated homograft degeneration. Eur Heart J. 2007;28:2503-9.

6. Urso S, Rega F, Meuris B, Gewillig M, Eyskens B, Daenen W, et al. The Contegra ${ }^{\circledR}$ conduit in the right ventricular outflow tract is an independent risk factor for graft replacement. Eur J Cardiothorac Surg. 2011;40:603-9.

7. Jashari R, Goffin Y, Van Hoeck B, Vanderkelen A, du Verger A, Fan Y, et al. Belgian and European experience with the European Homograft Bank (EHB) cryopreserved allograft valves. Assessment of a 20 year activity. Acta Chir Belg. 2010;110:280-90.

8. Butera G, Milanesi O, Spadoni I, Piazza L, Donti A, Ricci C, et al. Melody ${ }^{\circledR}$ transcatheter pulmonary valve implantation. Results from the registry of the Italian Society of Pediatric Cardiology. Catheter Cardiovasc Interv. 2013;81:310-6.

9. Malekzadeh-Milani S, Ladouceur M, Patel M, Boughenou FM, Iserin L, Bonnet D, et al. Incidence and predictors of Melody ${ }^{\circledR}$ valve endocarditis: a prospective study. Arch Cardiovasc Dis. 2015;108:97-106.

10. Van Dijck I, Budts W, Cools B, Eyskens B, Boshoff DE, Heying R, et al. Infective endocarditis of a transcatheter pulmonary valve in comparison with surgical implants. Heart. 2015;101:788-93.

11. Peetermans M, Verhamme P, Vanassche T. Coagulase activity by Staphylococcus aureus: a potential target for therapy? Semin Thromb Hemost. 2015;41:433-44.
12. Elgharably H, Hussain ST, Shrestha NK, Blackstone EH, Pettersson GB. Current hypotheses in cardiac surgery: biofilm in infective endocarditis. Semin Thorac Cardiovasc Surg. 2016;28:56-9.

13. Butcher JT, Mahler GJ, Hockaday LA. Aortic valve disease and treatment: the need for naturally engineered solutions. Adv Drug Deliv Rev. 2011;63:242-68.

14. Schoen FJ, Levy RJ. Bioprosthetic heart valve failure: pathology and pathogenesis. Cardiol Clin. 1984;2:717-39.

15. Massel DR, Little SH. Antiplatelet and anticoagulation for patients with prosthetic heart valves. Cochrane Database Syst Rev 2013; 7:CD003464.

16. Jalal Z, Galmiche L, Lebeaux D, Villemain O, Brugada G, Patel M, et al. Selective propensity of bovine jugular vein material to bacterial adhesions: an in-vitro study. Int J Cardiol. 2015;198:201-5.

17. Veltrop MH, Beekhuizen H, Thompson J. Bacterial species- and strain-dependent induction of tissue factor in human vascular endothelial cells. Infect Immun. 1999;67:6130-8.

18. Hauser-Gerspach I, Kulik EM, Weiger R, Decker EM, Von Ohle C, Meyer J. Adhesion of Streptococcus sanguinis to dental implant and restorative materials. in vitro. Dent Mater J. 2007;26:361-6.

19. Vanassche T, Peetermans M, Van Aelst LN, Peetermans WE, Verhaegen J, Missiakas DM, et al. The role of staphylothrombin-mediated fibrin deposition in catheter-related Staphylococcus aureus infections. J Infect Dis. 2013;208:92-100.

20. George NPE, Konstantopoulos K, Ross JM. Differential kinetics and molecular recognition mechanisms involved in early versus late growth phase Staphylococcus aureus cell binding to platelet layers under physiological shear conditions. J Infect Dis. 2007;196:639-46.

21. George NPE, Wei Q, Shin PK, Konstantopoulos K, Ross JM. Staphylococcus aureus adhesion via Spa, ClfA, and SdrCDE to immobilized platelets demonstrates shear-dependent behavior. Arterioscler Thromb Vasc Biol. 2006;26:2394-400.

22. Claes J, Vanassche T, Peetermans M, Liesenborghs L, Vandenbriele C, Vanhoorelbeke K, et al. Adhesion of Staphylococcus aureus to the vessel wall under flow is mediated by von Willebrand factor-binding protein. Blood. 2014;124: 1669-76.

23. Thewes N, Thewes A, Loskill P, Peisker H, Bischoff M, Herrmann M, et al. Stochastic binding of Staphylococcus aureus to hydrophobic surfaces. Soft Matter. 2015;11:8913-9.

24. Scheld WM, Valone JA, Sande MA. Bacterial adherence in the pathogenesis of endocarditis. Interaction of bacterial dextran, platelets, and fibrin. J Clin Invest. 1978;61:1394-404.

25. Gould K, Ramirez-Ronda CH, Holmes RK, Sanford JP. Adherence of bacteria to heart valves. in vitro. J Clin Invest. 1975;56:1364-70.

26. Koolbergen DR, Hazekamp MG, de Heer E, Bruggemans EF, Huysmans HA, Dion RA, et al. The pathology of fresh and cryopreserved homograft heart valves: an analysis of forty explanted homograft valves. J Thorac Cardiovasc Surg. 2002;124:689-97.

27. Schneider H, Vogt M, Boekenkamp R, Hoerer J, Eicken A, Foth R, et al. Melody ${ }^{\circledR}$ transcatheter valve: histopathology and clinical implications of nine explanted devices. Int J Cardiol. 2015;189:124-31.

28. Lower SK, Lamlertthon S, Casillas-Ituarte NN, Lins RD, Yongsunthon R, Taylor ES, et al. Polymorphisms in fibronectin binding protein A of Staphylococcus aureus are associated with infection of cardiovascular devices. Proc Natl Acad Sci U S A. 2011;108:18372-7.

29. Jalal Z, Galmiche L, Beloin C, Boudjemline Y. Impact of percutaneous pulmonary valve implantation procedural steps on leaflets histology and mechanical behaviour: an in vitro study. Arch Cardiovasc Dis. 2016;109:465-75.

30. Berdajs DA, Mosbahi S, Charbonnier D, Hullin R, von Segesser LK. Analysis of flow dynamics in right ventricular outflow tract. J Surg Res. 2015;197:50-7.

Key Words: congenital heart disease, congenital heart disease surgery, endocarditis, prosthetic heart valve, valved conduit 

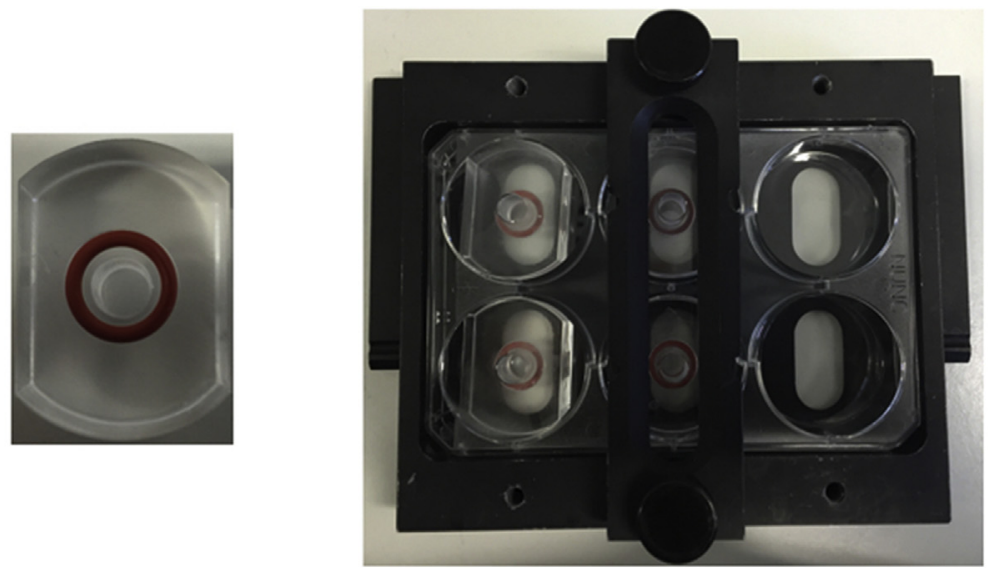

A

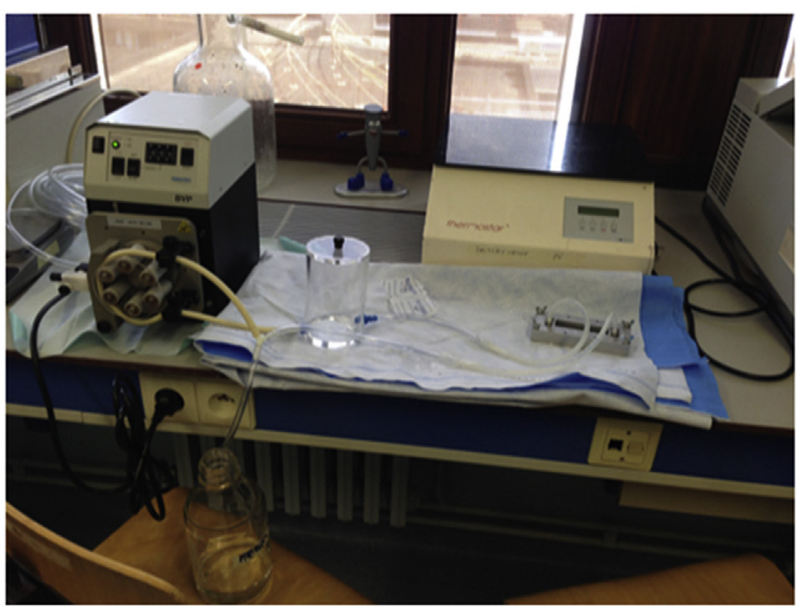

B

FIGURE E1. A, Image of the poly(methyl methacrylate) inlets with ring rubber gaskets (in-house design) mounted on a 6-well plate and fixed, using a metal frame (in-house design). B, Newly developed flow chamber (in-house design; Department of Tissue Engineering and Textile Implants, AMEHelmholtz Institute for Biomedical Engineering, Aachen, Germany) and the full installation for the bacterial perfusion. 

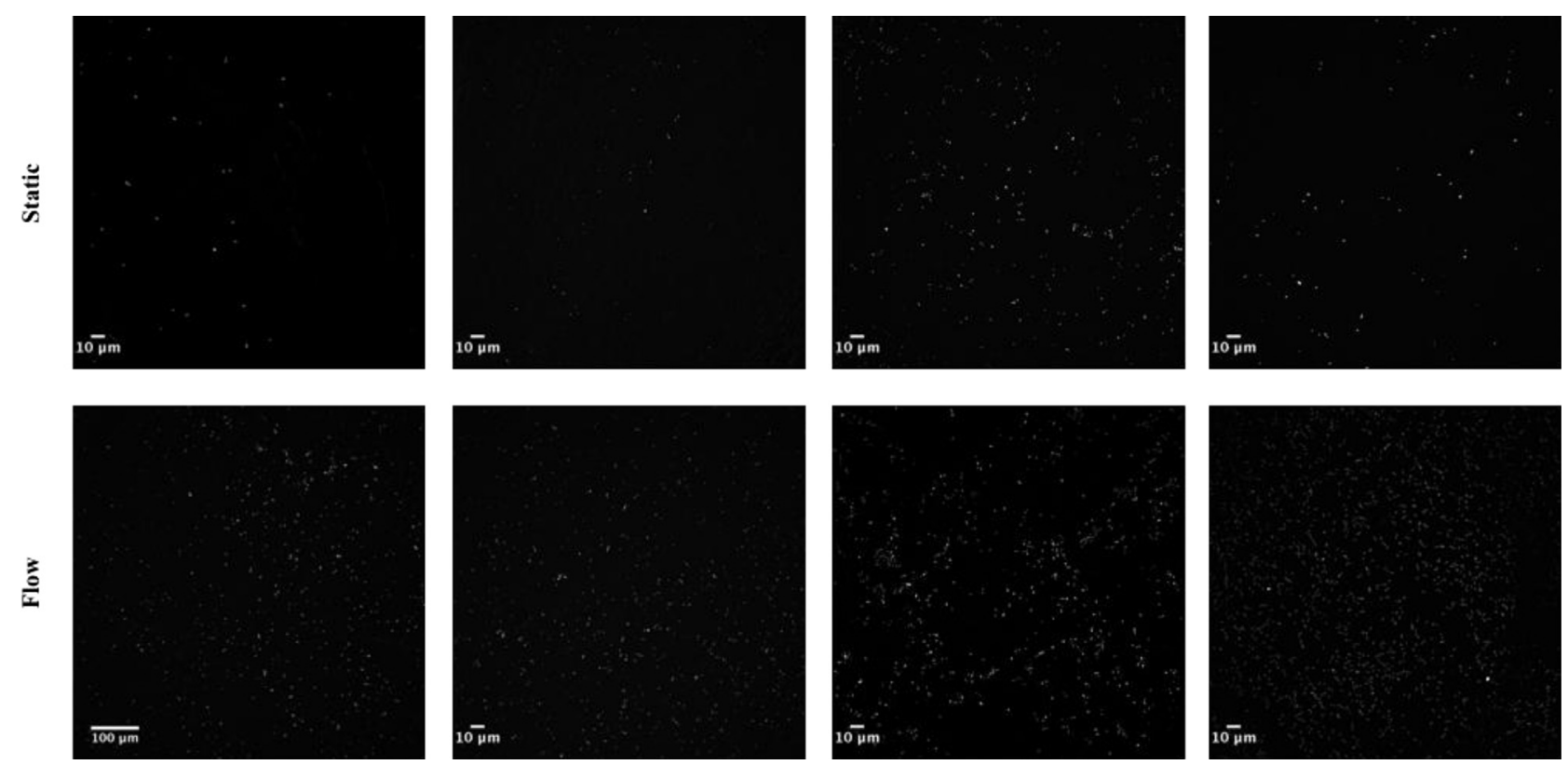

FIGURE E2. Visualization of S aureus Cowan adhesion to graft tissues using fluorescence microscopy. Left to right: BJV conduit wall, BJV conduit leaflet, $\mathrm{CH}$ wall, and $\mathrm{CH}$ leaflet.
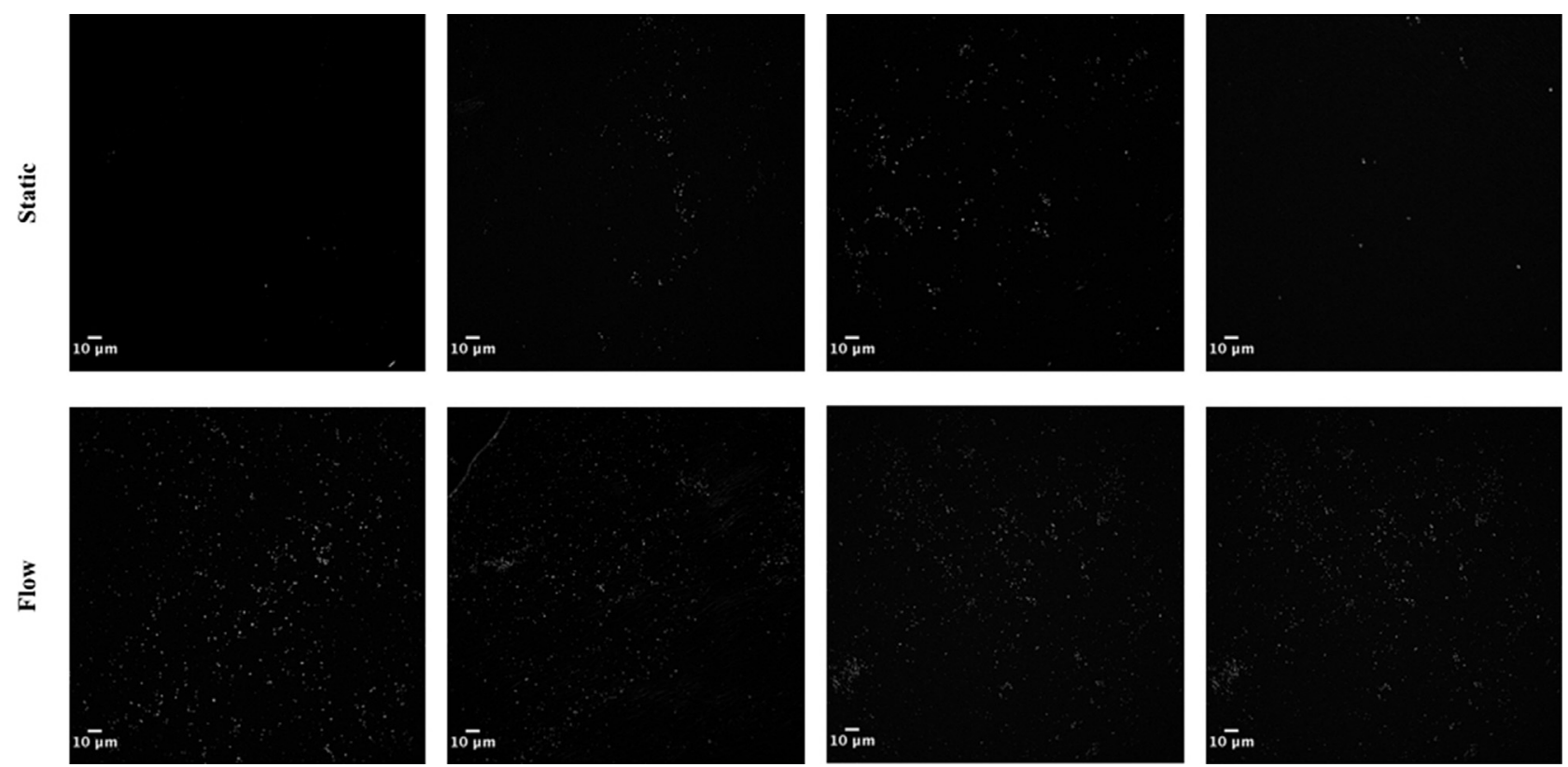

FIGURE E3. Visualization of S epidermidis ATCC 149900 adhesion to graft tissues using fluorescence microscopy. Left to right: BJV conduit wall, BJV conduit leaflet, $\mathrm{CH}$ wall, and $\mathrm{CH}$ leaflet. 

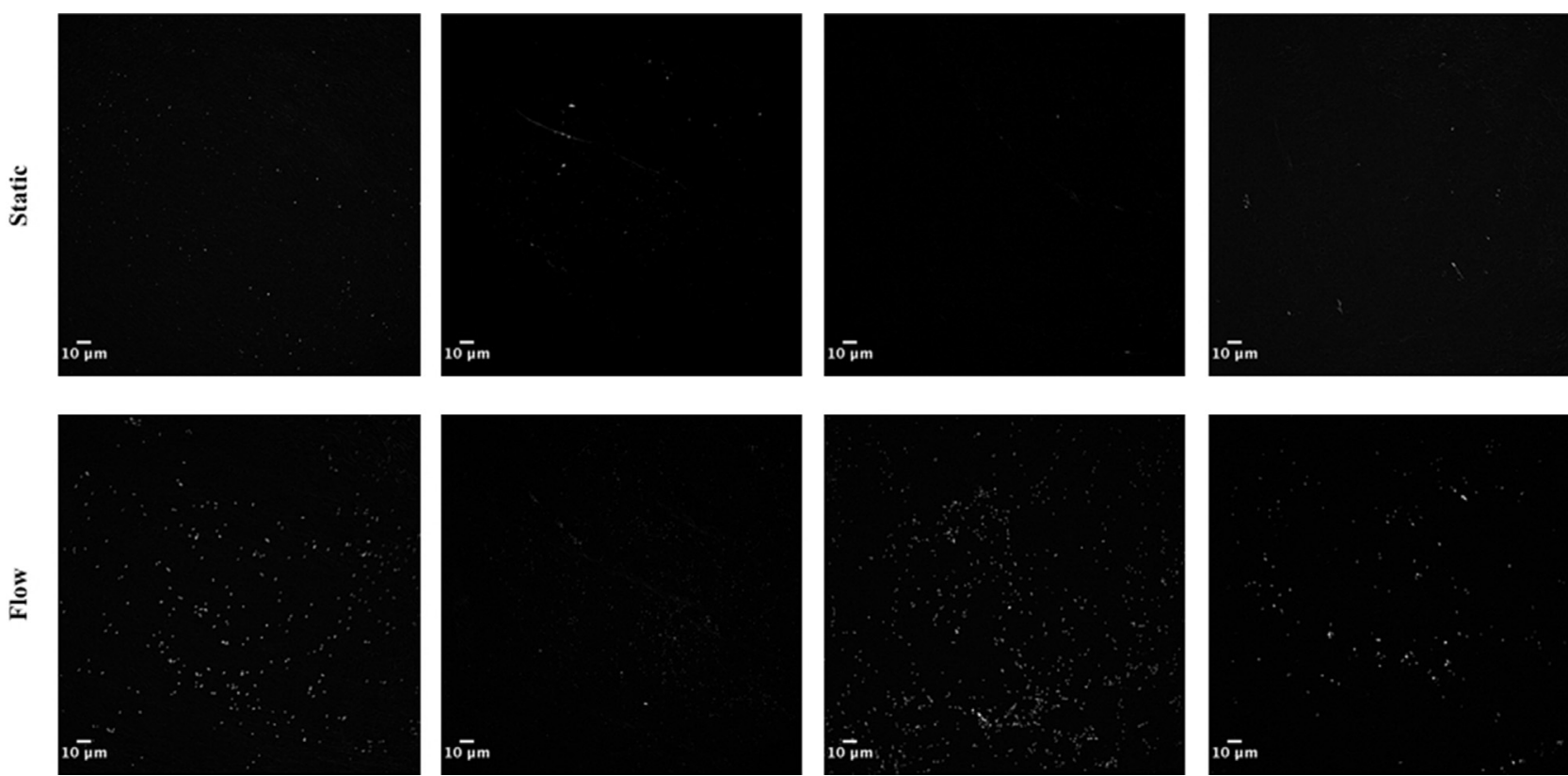

FIGURE E4. Visualization of $S$ sanguinis NCTC 7864 adhesion to graft tissues using fluorescence microscopy. Left to right: BJV conduit wall, BJV conduit leaflet, $\mathrm{CH}$ wall, and $\mathrm{CH}$ leaflet.
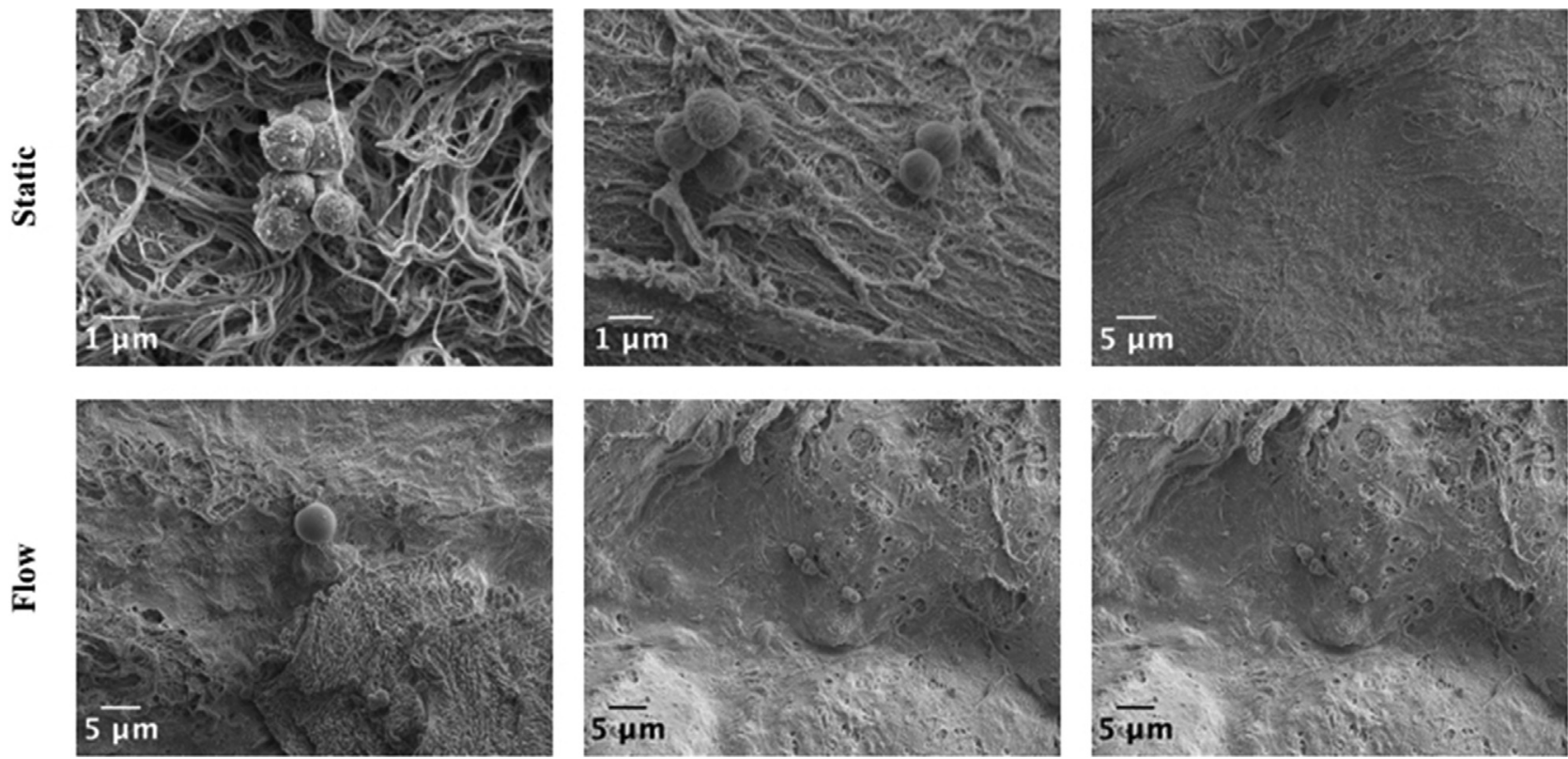

FIGURE E5. Visualization of S epidermidis ATCC 149900 adhesion to graft tissues using SEM. Left to right: BJV conduit wall, CH wall, and CH leaflet. 

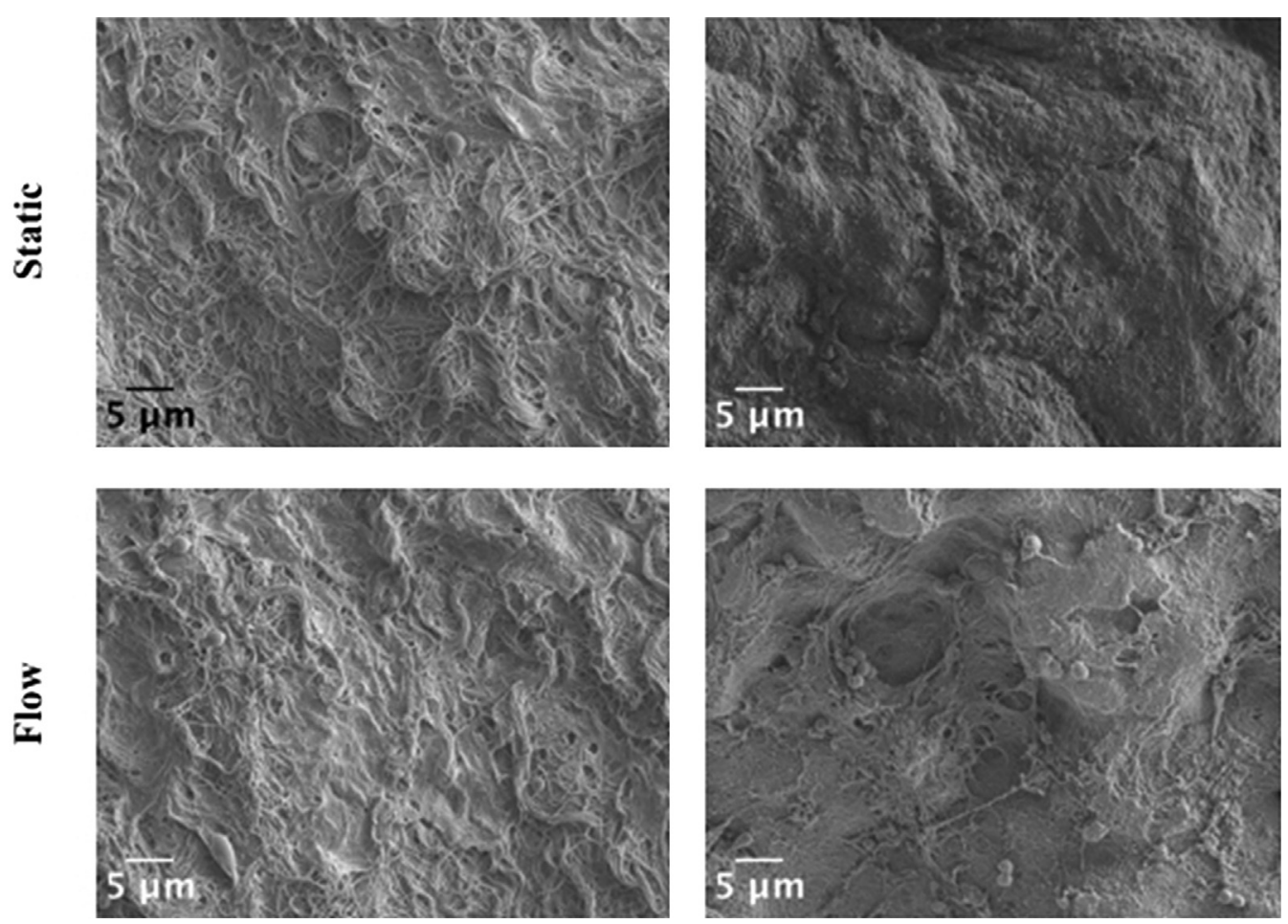

FIGURE E6. Visualization of $S$ sanguinis NCTC 7864 adhesion to graft tissues using SEM. Left to right: BJV conduit wall and CH wall. 